\title{
Om forfatterne
}

\section{HANS-HENRIK HOLM}

Jean Monnet Professor i verdenspolitik, Danmarks Journalisthøjskole. Bestyrelsesformand for Center for Journalistiske Universitetsuddannelser, Aarhus Universitet. Primære forskningsfelter har været international politik og udenrigsjournalistik. Deltager i de kommende år i et store forskningsprojekt om Public Service sammen med forskere fra Aarhus Universitet og Danmarks Journalisthøjskole.

E-mail: hhh@djh.dk.

\section{LAURITS HARMER LASSEN}

Chefredaktør på Københavneravisen. Uddannet cand. comm. og journalist fra Roskilde Universitetscenter og bachelor i Offentlig Administration. Har tidligere været ansat på dagbladet Børsen, Ugebrevet A4 og Ritzaus Bureau.

E-mail:lhl@koebenhavneravisen.dk

\section{SøREN KJELLBERG ISHøY}

Journalist på Ekstra Bladet. Uddannet cand. comm. og journalist fra Roskilde Universitetscenter og bachelor i Offentlig Administration. Har tidligere været ansat på Jyllands-Posten og MetroXpress.

E-mail: sorenishoy@myinternet.dk

\section{PETER BRO}

Ph.d., cand.comm., lektor i journalistik, Center for Journalistik på Syddansk Universitet. Primære forskningsområder er politisk journalistik og -kommunikation med forkus fokus på områder som public journalism, borger-journalistik og aktions-journali- 
stik. Arbejder i denne tid på et større forskningsprojekt om netværk i nyhedsmedierne.

E-mail: ppe@journalism.sdu.dk

\section{KEVIN WILLIAMS}

Professor of Media and Communication Studies at Swansea University in Wales, UK. He has been a visiting scholar at the Danish National School of Journalism and has recently published a book on European Media Studies (Arnold, 2005). He is presently writing a book for Sage on International Journalism as well as researching into the history of the press in Britain.

E-mail:k.m.williams@swan.ac.uk

\section{LARS KABEL}

Cand. phil. og journalist. Lektor på Danmarks Journalisthøjskole. Underviser internationale studerende i International Newsgathering og danske studerende i medieteori. Udfører analyse og forskning med særligt fokus på nyhedsjournalistik og international nyhedsformidling. Gennemfører udviklingsprojekter på medierne blandt andet i samarbejde med udlandsredaktionen på TV2 Nyhederne. Har skrevet flere bøger og udredninger for Danida om kommunikation, mediedækning og den 3. verden.

\section{MARK ØRSTEN}

Cand. scient. adm., ph.d. i Journalistik og ansat som adjunkt ved Roskilde Universitetscenter Afdeling for Journalistik. Mark Ørsten er forfatter til det første studie om europæiseringen af danske nyhedsmedier. Han desuden medredaktør og medforfatter til bogen 'Krigen i medierne, medierne i krig' om nyhedsmediernes dækning af Irak-krigen. Bogen er et resultat af forskningsnetværket MODINET (Medier og Demokrati i Netværkssamfundet). Mark Ørsten forsker i øjeblikket i erhvervsjournalistik som en del af forskningsprojektet PRO-MEDIA.

E-mail: oersten@ruc.dk 


\section{ABONNEMENT PÅ JOURNALISTICA}

Løssalg enkeltnumre pr. stk: 128,- kr.

Abonnement tre numre pr. år: 328,- kr.

Studieabonnement tre numre pr. år: 248,- kr.

Bestilles hos din lokale boghandel eller direkte hos: ajour@djh.dk

Husk at oplyse: Navn, postadresse, telefon og e-post.

\section{OPTAGELSE AF ARTIKLER}

Journalistica optager originale forskningsartikler, som både er af høj faglig kvalitet, men også formidlet på en måde, som gør de faglige kvaliteter tilgængelige for forskere, studerende og praktikere. Derfor vurderes artikler af såvel faglige redaktører som formidlingsredaktører.

Yderligere oplysninger: www.journalistica.dk 